PRINT ISSN 1119-8362

Electronic ISSN 1119-8362
Full-text Available Online at

https://www.ajol.info/index.php/jasem

http://ww.bioline.org.br/ja
J. Appl. Sci. Environ. Manage.

Vol. 25 (4) 663-667 April 2021

\title{
Physicochemical and Heavy Metal Assessment of the Udu River, Delta State, Nigeria
}

\section{${ }^{* 1}$ OKOBIEBI, OO; ${ }^{2 * O K O B I E B I, ~ B O ~}$}

\author{
Centre of Excellence in Geoscience and Petroleum Engineering ${ }^{l}$, Department of Science Laboratory Technology ${ }^{2}$, University of Benin, \\ Nigeria \\ *Corresponding author: Email: becky.obinyan@uniben.com, Tel: +2347030428499
}

\begin{abstract}
The Udu River is a major source of commerce and provides water for agricultural and domestic use to the Udu people, hence we studied the physicochemical parameters ( $\mathrm{pH}$, electrical conductivity, TSS, TDS, turbidity, Salinity, DO, COD, BOD, chlorides, sodium, potassium, total hardness, alkalinity, nitrates, ammonium, sulphates) as well as the evaluation of the degree of metal contamination (iron, zinc, cadmium, nickel, copper and lead) present in the samples. The analyses carried out revealed water samples were acidic, $\mathrm{pH}$ below 7 , temperature ranged from $29.5^{\circ} \mathrm{C}-$ $32.7^{\circ} \mathrm{C}$ which was above WHO permissible limit $25^{\circ} \mathrm{C}$, low levels of Dissolve oxygen DO (DO: $\mathrm{max}=6.5 \mathrm{mg} / \mathrm{L}$ below WHO limit of $7.5 \mathrm{mg} / \mathrm{L}$ ) and BOD ranges did not exceed the suggested 4.5mg/L (WHO max. limit). Concerning the heavy metals, the examined results showed lead, nickel, copper and zinc all below the WHO max limit. A significant increase in the concentration of Iron was noticed in Ovwian sampling site, also there was also build of cadmium above WHO limit $0.003 \mathrm{mg} / \mathrm{L}$ at Igbogidi.
\end{abstract}

\section{DOI: https://dx.doi.org/10.4314/jasem.v25i4.28}

Copyright: Copyright (C) 2021 Okobiebi and Okobiebi. This is an open access article distributed under the Creative Commons Attribution License (CCL), which permits unrestricted use, distribution, and reproduction in any medium, provided the original work is properly cited.

Dates: Received: 03 February 2021; Revised: 26 March 2021; Accepted: 05 April 2021

Keywords: $\mathrm{pH}$, heavy metals, physicochemical, river, permissible limit

Water constitutes an integral part of man's life as well as the earth surface; hence continuous research is imperative to ascertain its quality due to one form of human activity or the other. In many locations the contamination of surface and sub- surface waters by domestic and industrial waste causes great environmental challenges Prescott et al., (2000).

Water (saline water) makes up approximately $97 \%$ of the water in the earth, while the other $3 \%$ of the earth's water is fresh water contained in rivers, lakes and ground water from which human and animals get their water supply Al-Ghamdi et al., (2014) Only about $0.25 \%$ of the earth fresh water is surface water contained in rivers, ponds, dams, streams and lakes (El-Dessouki and Ettouney, 2002; Kalogirou, 2005; Eltawil et al., (2009).

The Udu River is of great importance to the people of Udu whose main occupation is fishing and agriculture. The River is a source of sea food, water for farmers of channel fish ponds and domestic purposes. Recent trends like the loss of commercial fishes, contaminated sea foods, species extinction and the alteration in the water quality has increased anxiety of the rural inhabitant, as such the study to know the physicochemical and heavy metal characteristics of the river is a prerequisite to the people of Udu local government Area.

\section{MATERIALS AND METHODS}

Description of study area: The Udu River which is a large tributary of the Warri River is located at Udu local government area of Delta state and spans over $48 \mathrm{~km}^{2}$. The river has its source from Aboh in Delta North between longitude $6.20^{\circ} \mathrm{N}$ and latitude $5.45^{\circ} \mathrm{E}$ and flows southwest where it is joined by a large number of creeks from where it empties into the very brackish Forcados River and finally into the Atlantic Ocean (Udo, 1975).

Sample collection and preparation: Samples for both physicochemical and heavy metal analysis were collected directly from the different River locations (Aladja, Oleri, Opete, Ovwian, Udu Bridge, Ekete, Igbogidi and Ogbe- Ijaw) into $750 \mathrm{ml}$ water cans that were washed clean and rinsed with sample water. The $\mathrm{pH}$ and temperature were taken on site with a $\mathrm{pH}$ meter Model Testr-1 and the electrical hand thermometer respectively. Samples for heavy metal analyses were pre- concentrated and made acidic by adding $0.75 \mathrm{ml}$ of $0.1 \mathrm{M} \mathrm{HNO}_{3}$ solution and covered immediately.

Physicochemical/heavy metal analysis: All field meters and equipment were checked and appropriately 
calibrated according to the manufacturers' instructions. The physicochemical parameters of water quality comprising of temperature, $\mathrm{pH}$, turbidity, total suspended solid, total dissolve solid, hardness, magnesium hardness, salinity, conductivity, sulfate $\left(\mathrm{SO}_{2-}\right)$ phosphate $\left(\mathrm{PO}_{4}\right)$, nitrate $\left(\mathrm{NO}_{3-}\right)$, nitrite $\left(\mathrm{NO}_{2-}\right)$ ammonia $\left(\mathrm{NH}_{3}\right)$, biological oxygen demand (BOD) and chemical oxygen demand (COD), Heavy metal concentrations, including cadmium $(\mathrm{Cd})$; copper $(\mathrm{Cu})$; aluminium $(\mathrm{Al})$; lead $(\mathrm{Pb})$; Zinc $(\mathrm{Zn})$; mercury $(\mathrm{Hg})$; Iron $(\mathrm{Fe})$ and Manganese $(\mathrm{Mn})$ were analysed using the APHA, 2006 methodology.

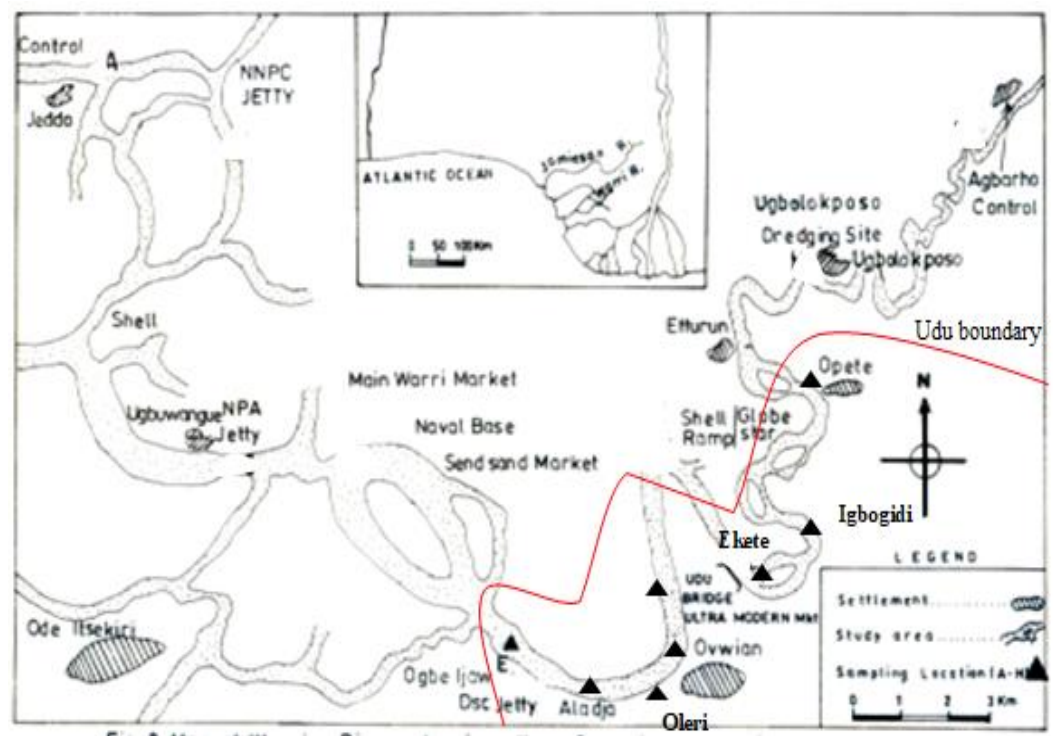

Fig. 1: Map of study area indicating sampling points (modified from the N. P.A., 2005)

\section{RESULTS AND DISCUSSION}

Hydrogen potential: The $\mathrm{pH}$ value in this study ranged from 5.87 to 6.32 at all locations, which is low, slightly acidic and all fell below the (World Health Organisation) WHO, $2011 \mathrm{pH}$ value lower permissible limit of 6.5. This is similarly to Aghoghovwia, 2014 findings and corroborates the claim of Enujiugha and Nwanna (2004) that a high organic content will tend to decrease the $\mathrm{pH}$ because of the Carbonate chemistry. The results are similar to those of the Udu River because of the close proximity of the water bodies.

Temperature: Table 1 showed a temperature range from $29.50^{\circ} \mathrm{C}-32.70^{\circ} \mathrm{C}$ that is higher than the WHO (2011) permissible limit of $25^{\circ} \mathrm{C}$. Ovwian had the highest temperature this could be because of the proximity of the sampling point to the Ovwian market and the effluent discharge point from Premium Steel Company, which usually has higher temperature than recipient water. Increased temperature increases the rate of chemical reactions and decreases solubility of gases (especially oxygen) in water. Respiration value of aquatic organisms increases leading to increased oxygen consumption and increased decomposition of organic matter Enujiugha and Nwanna (2004). This is evident in this study as the study area samples are low in dissolved oxygen, with attendant high temperature.
Total Dissolve Solid: TDS levels in study area ranged from 23.80 - $49.70 \mathrm{mg} / \mathrm{L}$, which are within maximum permissible limits WHO, 2011 of $500 \mathrm{mg} / \mathrm{L}$. Seiyaboh et al. (2013) reported a similar average TDS value.

Conductivity: Conductivity readings from the 8 samples site ranged from $40.11-73.84(\mu \mathrm{s} / \mathrm{cm})$ and an average value of $52.56 \mu \mathrm{s} / \mathrm{cm}$ which were below the WHO max. limit of $250 \mu \mathrm{s} / \mathrm{cm}$.

Total suspended solid: TSS had an average value of $24.75 \mathrm{mg} / \mathrm{L}$ and ranged from $15 \mathrm{mg} / \mathrm{L}-45 \mathrm{mg} / \mathrm{L}$. Three sampling points Aladja, Oleri and Ogbe-Ijaw were above the WHO maximum permissible limit of $20 \mathrm{mg} / \mathrm{L}$.

Turbidity: Turbidity measurement had similar trends with the TSS with locations Aladja, Oleri and OgbeIjaw all higher than the WHO maximum permissible limit of 25 NTU. Owvian had the lowest Turbidity of 11.91 indicating that the river water at Ovwian is clearer and less cloudy than the others.

Sulphate: From Table 1, the sulphate concentration ranged from $0.30-0.92 \mathrm{mg} / \mathrm{L}$ and shows that the $\mathrm{WHO}$ maximum permissible limit of $250 \mathrm{mg} / \mathrm{L}$ was not breached by any of the samples collected from the eight locations. 
Phosphate: concentration ranged from $0.11-0.57$ $\mathrm{mg} / \mathrm{L}$ and well below the WHO permissible limit of $1.0 \mathrm{mg} / \mathrm{L}$.

Nitrate: nitrates concentration in the sampling points ranged from $0.11-0.31 \mathrm{mg} / \mathrm{L}$ well below the permissible limit of $50 \mathrm{mg} / \mathrm{L}$. These low concentrations may be due to utilization by the species in absence of sufficient oxygen, which proves Clinton and Kathy work of 2003 that phosphate concentration is directly proportional to nitrate concentration.

Alkalinity: From the table shows that Aladja has the highest concentration of $9.26 \mathrm{mg} / \mathrm{L}$, followed by Ekete with $8.41 \mathrm{mg} / \mathrm{L}$ and Oleri with $8.32 \mathrm{mg} / \mathrm{L}$ and lowest at Udu Bridge with a concentration of $3.19 \mathrm{mg} / \mathrm{L}$.

Total hardiness (TH): $\mathrm{TH}$ is very important in the physicochemical analysis of any water analysis. It is an indication of the ability of the water to form lather when soap is applied. The total hardness value comprises on the calcium and magnesium content of the water. Table 1 show that $\mathrm{TH}$ ranged from 15 -
$35 \mathrm{mg} / \mathrm{L}$ which are all below the WHO permissible limit of $75 \mathrm{mg} / \mathrm{L}$.

Dissolved Oxygen: Dissolved oxygen (DO) recoded in the study area ranged from $3.10 \mathrm{mg} / \mathrm{L}-6.50 \mathrm{mg} / \mathrm{L}$ and below the WHO minimum recommended standard of $7.50 \mathrm{mg} / \mathrm{L}$. this is similar to studies carried by Tesi et al., (2019). The low DO values obtained in this study may be attributable to high organic matter content which high microbial oxidation Prasanna and Ranjan, 2010; Mandal et al., (2011).

Biological oxygen Demand: this is a very important with a WHO maximum permissible limit of 4.00 $\mathrm{mg} / \mathrm{L}$. The values recorded in the study area ranges from $0.79 \mathrm{mg} / \mathrm{L}-1.50 \mathrm{mg} / \mathrm{L}$.

These were all below the WHO maximum limit which according to Vowels and Connel (1980) and Mara,1983 classification of aquatic pollution with respect to BOD puts the Udu river between nonpolluted and moderately polluted in some sample points.

Table 1- Result of River Water analysis (Study Area)

\begin{tabular}{|c|c|c|c|c|c|c|c|c|c|c|}
\hline $\mathrm{S} / \mathrm{N}$ & Parameters & $\frac{\stackrel{0}{0}}{\frac{0}{\Delta}}$ & $\stackrel{d}{\dot{d}}$ & 变 & $\frac{0}{0}$ & 롬 & $\frac{\pi}{\frac{\pi}{\sigma}}$ & $\frac{\pi}{0}$ & $\begin{array}{l}3 \\
0 \\
80 \\
00 \\
0\end{array}$ & 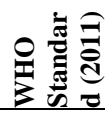 \\
\hline 1 & $\mathrm{pH}$ & 6.15 & 6.19 & 5.98 & 6.02 & 5.87 & 6.32 & 6.09 & 5.96 & $6.5-8.5$ \\
\hline 2 & Temp. $\left({ }^{\circ} \mathrm{C}\right)$ & 30.80 & 29.50 & 32.70 & 30.10 & 32.60 & 29.70 & 30.80 & 31.90 & 25.00 \\
\hline 3 & TDS (mg/L) & 43.40 & 49.70 & 27.30 & 23.80 & 28.30 & 37.70 & 26.81 & 28.70 & 500 \\
\hline 4 & COND $(\mu \mathrm{s} / \mathrm{cm})$ & 70.21 & 73.84 & 49.82 & 40.11 & 47.29 & 55.28 & 42.31 & 41.62 & 250 \\
\hline 5 & $\mathrm{DO}(\mathrm{mg} / \mathrm{L})$ & 4.60 & 3.10 & 5.30 & 4.20 & 6.20 & 6.50 & 4.90 & 6.10 & 7.50 \\
\hline 6 & $\mathrm{BOD}_{5}(\mathrm{mg} / \mathrm{L})$ & 1.20 & 1.50 & 0.97 & 1.10 & 0.83 & 0.79 & 1.20 & 0.97 & 4.00 \\
\hline 7 & TSS (mg/L) & 15.00 & 45.00 & 15.00 & 20.00 & 18.00 & 40.00 & 30.00 & 15.00 & 20.00 \\
\hline 8 & Turbidity (N.T.U) & 14.09 & 39.77 & 11.91 & 17.44 & 16.14 & 38.21 & 27.85 & 14.78 & $5-25$ \\
\hline 9 & Salinity (mg/L) & 11.26 & 12.35 & 6.45 & 5.28 & 6.61 & 7.43 & 5.98 & 6.06 & \\
\hline 10 & Sulphate $(\mathrm{mg} / \mathrm{L})$ & 0.90 & 0.92 & 0.71 & 0.55 & 0.59 & 0.51 & 0.39 & 0.43 & 2.50 \\
\hline 11 & Phosphate (mg/L) & 0.43 & 0.57 & 0.22 & 0.19 & 0.12 & 0.27 & 0.11 & 0.25 & 1.00 \\
\hline 12 & Nitrate $(\mathrm{mg} / \mathrm{L})$ & 0.29 & 0.31 & 0.16 & 0.21 & 0.15 & 0.19 & 0.11 & 0.15 & 50.00 \\
\hline 13 & Alkalinity $\left(\mathrm{mg} / \mathrm{L}\right.$, as $\left.\mathrm{CaCO}_{3}\right)$ & 8.41 & 7.71 & 3.45 & 3.97 & 3.19 & 9.26 & 8.32 & 3.33 & \\
\hline 14 & Total hardiness (mg/L) & 32.0 & 29.0 & 17.0 & 15.0 & 19.0 & 35.0 & 20.0 & 18.0 & 75.00 \\
\hline 15 & Calcium (mg/L) & 7.56 & 6.64 & 3.29 & 2.85 & 4.41 & 6.67 & 4.98 & 3.75 & 5.00 \\
\hline 16 & Magnesium (mg/L) & 3.27 & 2.81 & 1.43 & 1.27 & 2.02 & 2.54 & 1.85 & 1.21 & 50.0 \\
\hline 17 & $\mathrm{COD}(\mathrm{mg} / \mathrm{L})$ & 2.54 & 3.42 & 2.33 & 2.74 & 2.08 & 1.76 & 2.64 & 2.39 & 10.0 \\
\hline \multicolumn{11}{|c|}{ Heavy Metals } \\
\hline 18 & Lead (mg/L) & 0.004 & $<\mathrm{BDL}$ & $<\mathrm{BDL}$ & 0.001 & $<\mathrm{BDL}$ & $<\mathrm{BDL}$ & $<\mathrm{BDL}$ & $<\mathrm{BDL}$ & 0.01 \\
\hline 19 & Cadmium (mg/L) & $<\mathrm{BDL}$ & $<\mathrm{BDL}$ & $<\mathrm{BDL}$ & $<\mathrm{BDL}$ & $<\mathrm{BDL}$ & 0.001 & $<\mathrm{BDL}$ & 0.003 & 0.003 \\
\hline 20 & Iron (mg/L) & 0.026 & 0.005 & 0.011 & 0.009 & 0.045 & 0.002 & $<\mathrm{BDL}$ & 0.008 & 0.03 \\
\hline 21 & Copper (mg/L) & 0.019 & 0.008 & $<\mathrm{BDL}$ & 0.005 & 0.013 & 0.007 & 0.004 & 0.001 & 0.05 \\
\hline 22 & Zinc $(\mathrm{mg} / \mathrm{L})$ & 0.307 & 0.514 & 0.227 & 0.083 & 0.065 & 0.027 & 0.109 & 0.221 & 3.00 \\
\hline 23 & Nickel (mg/L) & $<\mathrm{BDL}$ & 0.001 & $<\mathrm{BDL}$ & $<\mathrm{BDL}$ & $<\mathrm{BDL}$ & $<\mathrm{BDL}$ & $<\mathrm{BDL}$ & $<\mathrm{BDL}$ & 0.006 \\
\hline
\end{tabular}

BDL - Below Detection Limit, i.e. <0.001

Chemical Oxygen Demand: COD of the water samples presented in the Table 1 ranged from $1.79-$

$3.42 \mathrm{mg} / \mathrm{L}$ and the entire sampling site concentration were all below the maximum permissible limit of 100 $\mathrm{mg} / \mathrm{L}$. COD values were higher than their corresponding BOD values in the sampling sites. This may be attributable to the ratio of all oxygen oxidizable organic to all oxidizable organics as COD measures all the oxidizable organics while BOD measures the oxygen available for biological activities Okorafor et al., (2013). 
Heavy metal: The heavy metal tested (Iron, lead, Nickel, copper, zinc and cadmium) were below detectable limit and therefore below the maximum permissible limit of the WHO, except for iron and cadmium. Iron had significant build-up of $0.045 \mathrm{mg} / \mathrm{L}$ in Udu Bridge which could be caused by the production of barges along the shore line by Petroleum Training 1 Construction Company. Cadmium also had a build at the Igbogidi sampling point this might be as a result of the dumpsite up river in the Igbogidi town.

According to Damaskos and Papadopoulos (1983), the generally accepted indicators of water quality are dissolved oxygen and the biological oxygen demand; High oxygen depletion can be so severe as to affect fish life. If DO values fall below the minimum oxygen requirement for the particular species of fish, they are subjected to stress, which can result in mortality. The oxygen content of natural waters varies with temperature, salinity, turbulence, the photosynthetic activity of algae and plants, and atmospheric pressure Enijiugha and Nwanna (2004).

Conclusion: This study was to assess the physicochemical and heavy metal properties of the Udu River. The water samples analysed were within the permissible limit for potable water as recommended by WHO apart from instances such as $\mathrm{pH}$ and temperature, TSS, Iron and Cadmium concentrations at some sampling points which did not conform to standard. As such the water is not suitable for drinking without appropriate treatment and waste water disposal from industrial sites should be monitored as this may be the cause of high water temperature.

Acknowledgement: The authors appreciate the Chairman of Udu Local Government Area Hon. Jite Brown for his support and security to prevent any embarrassment while on location.

\section{REFERENCES}

Aghoghovwia, OA (2011). Physico-chemical characteristics of Warri River in the Niger Delta region of Nigeria. J. Environ. Issues Agric. Dev. Country, 3(2): 40-46

Al-Ghamdi, AY; Saraya, MEI; Al-Ghamdi, AO; Zabin, SA (2014). Study of physicochemical properties of the surface and ground water. Am. J. Environ. Sc. 10(3): 219-235

An, TD; Tsujimura, M; Phu, VL; Kawachi, A; Ha, DT (2004). Chemical characteristics of surface water and groundwater in coastal watershed, Mekong
Delta, Vietnam. Procedia Environ. Sci. 20: 712 721

APHA (American Public Health Association) (2006). Standard Methods for the Examination of Waters and Wastes Water, 20 $0^{\text {th }}$ ed. Washington, D.C., 161 $\mathrm{p}$

Dimowo, BO (2013). Assessment of some physicochemical parameters of River Ogun (Abeokuta, Ogun State, Southwestern Nigeria) in comparison with national and international standards. Int. J. Aquac. 3(15):79-84

El-Dessouki, HT; Ettouney, HM (2002). Fundamentals of Salt Water Desalination. Elsevier, Amsterdam, $690 \mathrm{p}$

Eltawil, MA; Zhengming, Z; Yuan, L (2009). A review of renewable energy technologies integrated with desalination systems. Renew. Sustain. Energy Rev, 13: 2245-2262.

Enujiugha, VN; Nwanna, IC (2004). Aquatic Oil Impact Indicators. J. Appl. Sci. Environ.Manag. 8(2):71-75.

Gupta, N; Yadav, KK; Kumar, V; Singh, D (2011). Assessment of physicochemical properties of Yamuna River in Agra City. Int. J. Chem. ech Res. 5(1): 528-531

Kalogirou, SA (2005), Seawater desalination using renewable energy sources. Prog. Energ. Comb. Sci. 31: 242-81

Mandal, S; Ray, S; Debnath, M; Ghosh, PB; Roy, M; Ray, S (2011). Dynamic modelling of dissolved oxygen in the creeks of Sagar Island, Hooghly Matlah estuarine system,West Bengal, India. Appl. Math. Model. 36(12): 5952- 5963.

Okorafor, KA; Effanga, EO; Andem, AB; George, UU; Amos, DI (2013). Spatial variation in physical and chemical parameters and macroinvertebrates in the intertidal regions of Calabar River, Nigeria. Greener J. Geol. Earth Sci. 1(2): 063-072

Okoye, CO; Iteyere, PO (2014). Physico-chemical characteristics of Warri River, Delta State Nigeria and possible implications. Int. J. Eng. Res. Technol. 3(4): 795-802

Prasanna, MB; Ranjan PC (2010). Physicochemical properties of water collected from Dhamra estuary. Int. J. Environ. Sci. 1(3): 334-343 
Prescott, LM; Harley, JP; Klein, DA (2000). Microbiology $4^{\text {th }}$ Edition, McGraw Hill Companies Incorporated USA: 963pp.

Seiyaboh, EI; Ogamba, EN; Utibe, DI (2013). Impact of dredging on the water quality of Igbedi Creek, Upper Nun River, Niger Delta, Nigeria. $J$. Environ. Sci. Toxicol. Food Technol. 7(5): 51-56.

Tesi, GO; Tesi, JA; Ogbuta, AA; Iniaghe, PO; Enete, CI (2019). Assessment of effect of sand mining activities on physicochemical properties and Metal concentrations of surface water of Warri River, Niger delta, Nigeria. FUDMA J. Sci., 3(1): $72-83$
Udo, KR (1975).Geographical Region of Nigeria. Heinemann Educational Books London, 212pp.

Vowels, PD; Connel, DW (1980). Experiments in environmental chemistry. Pergamin Press, New York

WHO (2011). Guideline for Drinking Water Quality. First Addendum to the Third Edition Volume 1 Recommendations.491 - 493 . 